\title{
遠心型血液成分分離装置を用いて血漿交換を安全に施行でき た血栓性血小板減少性紫斑病の小肾例
}

\author{
當間圭一郎＼cjkstart制野 勇介＼cjkstart宮下 徳久＼cjkstart長井 勇樹 \\ 青木 一憲＼cjkstart長谷川智巳 黒澤 寛史
}

兵庫県立こども病院小児集中治療科（７ 650-0047＼cjkstart兵庫県神戸市中央区港島南町 1-6-7）

Key words: (1) centrifugal therapeutic plasma exchange (cTPE), (2) membrane filtration therapeutic plasma exchange (mTPE), (3) thrombotic thrombocytopenic purpura (TTP)

\section{はじめに}

血漿交換 (plasma exchange, PE) は, 様々な疾患の 重症小児において行われるアフェレシス治療の一つで ある。本邦においては膜型血漿分離法 (membrane filtration therapeutic plasma exchange, mTPE) が行わ れているが, 海外では遠心型血漿分離法 (centrifugal therapeutic plasma exchange, cTPE) での報告も多い。 今回, 血栓性血小板減少性紫斑病 (thrombotic thrombocytopenic purpura, TTP)の小児に対し, 遠心型血 液成分分離装置 (Spectra Optia ${ }^{\circledR}$ ，テルモBCT) を用い てcTPEを低侵襲で安全に施行できたので報告する。

\section{症 例}

患者：4歳, 男児。身長 $100 \mathrm{~cm}$, 体重 $17.0 \mathrm{~kg}$ 。

既往歴：前駆 B 細胞急性リンパ性白血病

現病歴：腹痛と血小板減少 $\left(\right.$ Plt $\left.1.1 \times 10^{4} / \mu \mathrm{L}\right)$ で 発症し, a disintegrin-like and metalloproteinase with thrombospondin type 1 motifs 13 (ADAMTS13) 活性 低下とADAMTS13インヒビター陽性より後天性 TTPと診断した。ステロイドパルス療法と新鮮凍結 血漿 (fresh frozen plasma, FFP)の輸血で軽快したが, ステロイドを減量中に再燃したためPE施行目的に PICUへ入室した。PE開始前の血液検査では, Hb 7.6 g/dL, Ht 23.7\%, Plt $0.9 \times 10^{4} / \mu$ Lだった。
遠心型血液成分分離装置を用いてPEを施行した (Fig. 1)。脱血ラインとして右前腕に $24 \mathrm{G}$ の動脈路, 送血ラインとして左前腕に $22 \mathrm{G}$ の静脈路を確保した。 置換液はFFP 1,200 mL (70 mL/ kg) を用いた。脱血 の血液流量 (blood flow rate, $\mathrm{Qb}$ ) は $0.8 \mathrm{~mL} / \mathrm{kg} / \mathrm{min}$ を 維持し, 168 分で初回PEを終了した。抗凝固薬はクエ ン酸製剤 $\left(\mathrm{ACD}-\mathrm{A}\right.$ 液 ${ }^{\circledR}$, テルモ) を用い, 塩化カルシウ ムを回路返血側へ持続投与した。PE施行中，イオン化 カルシウム值は $0.80 〜 1.49 \mathrm{mmol} / \mathrm{L}$ で経過した。プラ イミングには濃厚赤血球を用い, $\mathrm{PE}$ 施行中の最低 $\mathrm{Hb}$ 值は7.0 g/dLだった。 4 回のPEで血小板数は $8.5 \times$ $10^{4} / \mu \mathrm{L}$ まで上昇し, 入室 6 日目に一般病棟へ転棟し た。その5日後にTTPが再燃し，同様の方法でPEを 6 回施行した。血小板数は $1.9 \times 10^{4} / \mu \mathrm{L}$ から $18.4 \times$ $10^{4} / \mu \mathrm{L}$ まで上昇した。計 10 回の $\mathrm{PE}$ は $\mathrm{Qb} \quad 0.6 \sim 1.2$ $\mathrm{mL} / \mathrm{kg} / \mathrm{min}$ で行い, 施行時間の平均值は $181 \pm 30$ 分 だった。 3 回目以降はプライミングに $0.9 \%$ 食塩水を使 用したが循環動態の変動は認めず，カルシウム以外の 電解質異常は認めなかった。 $\mathrm{PE}$ 施行中の鎮痛・鎮静 薬は不要で, 有害事象は認めなかった。

\section{考 察}

TPEはTTPをはじめとする様々な疾患で適応が認め られている1)。実施方法としてはmTPEと cTPEがあり, 前者は濾過により, 後者は遠心力により血漿の分離を行

Plasma exchange using a centrifugal therapeutic plasma exchange device safely performed in a child with thrombotic thrombocytopenic purpura

Keiichiro Toma, Yusuke Seino, Norihisa Miyashita, Yuki Nagai, Kazunori Aoki, Tomomi Hasegawa, Hiroshi Kurosawa

Division of Pediatric Critical Care Medicine, Hyogo Prefectural Kobe Children's Hospital(1-6-7 Minatojima-minami-machi, Chuo-ku, Kobe, Hyogo 6500047, Japan) 
(a)

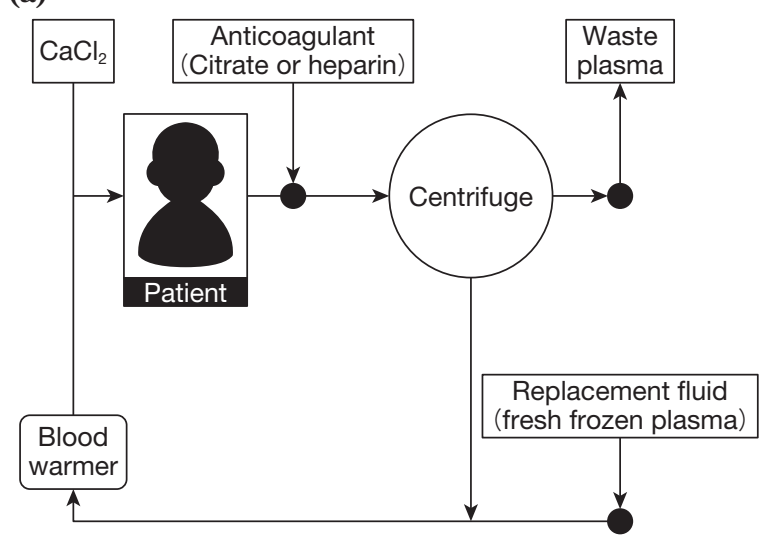

(b)

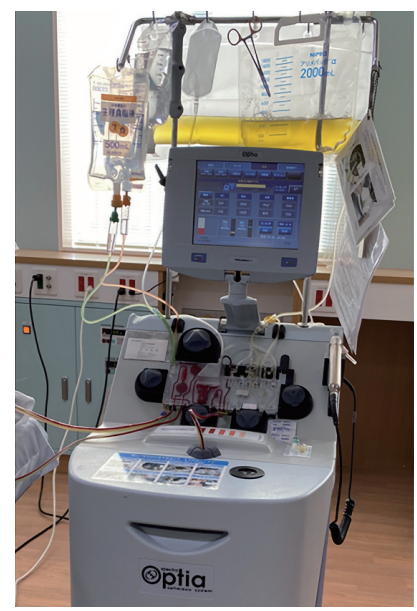

Fig. 1 cTPE system and the picture

(a) Schema of cTPE system, (b) Spectra Optia ${ }^{\circledR}$ (Terumo BCT).

cTPE, centrifugal therapeutic plasma exchange.

う2)。本邦を含むアジア諸国などにおいてはmTPEが 行われているが, 北米ではcTPEが主流である ${ }^{3) 。 ~}$

m TPEでは Qb確保のため中心静脈への透析カテー テルが必要であり, 小児では処置に際し気管挿管や全 身麻酔がほほ必須である。一方, cTPEは mTPEより も置換効率が良く, 低い血液流量での施行が可能であ り ${ }^{4)}$ ，末梢動脈路と末梢静脈路のみで施行できる。そ のため, (1)透析カテーテル確保に伴う鎮静や人工呼吸 管理が回避できる, (2)施行時間が短い4), (3)セットアッ プなどに要する時間が少ない4), といったメリットが ある。特に本症例のように著明な血小板減少や凝固障 害を呈している症例では, (1)のメリットは大きいと考 える。また, cTPEでの抗凝固薬はクエン酸を用いる のが標準であり ${ }^{2)}$, その投与量は機械のプログラムに より自動計算される。ヘパリンが不要なため, 出血リ スクの高い症例でもより安全に施行できる可能性があ る。さらに, cTPEでは末梢血管路を用いるため体位 制限が不要であり，患者快適性に優れている点でもメ
リットが大きいと考える。PEに伴う有害事象に関し ては, 介入を要さない軽度なものから重度なものまで いずれにおいても, mTPEより cTPEで少ないと報告 されている5)。ただし, cTPEでPEを施行する場合も, バイタルサインや電解質の厳密なモニタリングと有害 事象に迅速に対応できる体制は必要であり, 集中治療 室で施行すべきである。

cTPEのデメリットとしては, Spectra Optia ${ }^{\circledR}$ 用血 液回路 (Exchange セット, テルモ BCT) のプライミン グボリュームが $185 \mathrm{~mL}$ とTPEに比較して多いこと が挙げられ, PE中の貧血や循環動態への影響が危惧 される。したがって, 体格が小さい, または循環動態 が不安定でプライミングボリュームを最小限にしたい 症例では, mTPEが良い適応となる可能性がある6)。

\section{結 語}

TTPの小児例に対し, 遠心型血液成分分離装置を用 いて cTPEを施行した。末梢動脈路と末梢静脈路のみで 施行可能なため, mTPEと比較し低侵襲かつ短時間で 安全に施行でき，小児に対して有用であると思われた。

\section{謝 辞}

本症例の診療にご協力いただいた, 当院血液腫瘍内科の 小阪嘉之先生, 長谷川大一郎先生, 齋藤敦郎先生に深謝申し 上げます。

本症例の報告について患者家族から書面で同意を得た。

本稿の全ての著者には規定されたCOIはない。

\section{文 献}

1) Padmanabhan A, Connelly-Smith L, Aqui N, et al. Guidelines on the use of therapeutic apheresis in clinical practice - evidence-based approach from the writing committee of the american society for apheresis: the eighth special issue. J Clin Apher 2019;34:171-354.

2) Williams ME, Balogun RA. Principles of separation: indications and therapeutic targets for plasma exchange. Clin J Am Soc Nephrol 2014;9:181-90.

3) Malchesky PS, Koo AP, Skibinski CI, et al. Apheresis technologies and clinical applications: the 2007 international apheresis registry. Ther Apher Dial 2010;14:52-73.

4) Etienne Janssens M, Wakelin S. Centrifugal and membrane therapeutic plasma exchange- a mini-review. Eur Oncol Haematol 2018;14:105-9.

5) Mörtzell Henriksson M, Newman E, Witt V, et al. Adverse events in apheresis: an update of the WAA registry data. Transfus Apher Sci 2016;54:2-15.

6) Ciechanska E, Segal L, Wong H, et al. Plasma exchange using a continuous venovenous hemofiltration machine in children. Blood Purif 2005;23:440-5. 